\title{
Setting transformation and the meaning of residence in Sentani's Tribe Tradition
}

\author{
Deasy Widyastomo*, M. Faqih, Arina H. \\ Department of Architecture, Institute of Technology Sepuluh Nopember, Surabaya, Indonesian
}

Email address:

Widyastomo.uncen@gmail.com (D. Widyastomo), faqih@arch.its.ac.id (M. Faqih), arina.hayati@gmail.com (A. Hayati)

To cite this article:

Deasy Widyastomo, M. Faqih, Arina H.. Setting Transformation and the Meaning of Residence in Sentani's Tribe Tradition. Humanities and Social Sciences. Vol. 3, No. 1, 2015, pp. 32-41. doi: 10.11648/j.hss.20150301.15

\begin{abstract}
Architecture in Indonesia acquires various forms and technology tradition which reflects a variety of cultures and the richness of history inheritance. One of conventional architecture is traditional residence. Every culture in Indonesia has its own characteristic and it is uniquely established based the identity of each tribe in Indonesia. An anthropologist, Roxana Waterson (1991), said that the various traditional residences, generally in South east Asia and especially in Indonesia, obtained the identity and the uniqueness of Indonesian culture. Moreover, they are connected with the same philosophy. They have various forms and affluent of traditional architecture. According to Rapoport (1969), traditional architecture was a masterpiece which always attempted to adapt with its upbringing and tradition based on the belief within. Rapoport also added that the residentials and houses were established domain of communication and the characteristic of cultural expression. Thus, the community could articulate their culture background, religion, social structure and social connection among the people. This study was aimed to find the transformation in meaning on traditional residence of Sentani tribe in Danau Sentani. The research was qualitative study by interpreting and representing current or continuing situation. Moreover, this research focused on case study on residential by Sentani lake, especially the residence of the chief of New Doyo tribe. The findings of this study were the remaining and the transformation purpose of traditional residence. The Qualitative methods were used to find the meaning and search for the settings-changed of the room, ornaments, and the structure of the house in a traditional home Sentani tribe in Papua province, Indonesian. The traditional residence still maintained the room setting and symbolic culture inside which furnished the family meaning and aspect and the community tradition. Furthermore, based on the community system, there was fixed-feature element of separate room between man and woman. Then, there were semi-fixed-feature element and transformation aspect in the interior and the material construction for the house. For the transformation of interior, there were few different settings in the residence applied, such as: particular room for boys and the entrance that was adjoined man's and woman's room. This adaptation confirmed gender issue on how the man respected the woman in Sentani's tribe tradition.
\end{abstract}

Keywords: Transformation, Setting, Purpose, Residence, Traditional

\section{Introduction}

The architecture of traditional residence was a tangible fact of culture. For example, the architecture of traditional residence in coastal area has specific features. The previous disparity of the residences was always based on the various locations. Meanwhile, in time they purchased different forms on the residences' architecture. According to Rapoport, that improvement is continually and certainly happened. However, the desirable transformation was unchanged the essential characteristic of culture. The residence acquired to keep the essential features and change the nonessential features.

The transformation of the house, according to Rapoport
(1969), was not only the result of the physical factors but also. was a consequence of cultural factors. Rapoport divided the pattern of residential, into two groups of basic elements. They were physical elements, such as, climate conditions, construction methods, available materials and the technology. Furthermore, Rapoport (1983) added that the changes were certainly happened only for nonessential features without losing the cultural characteristic.

A house was one of the basic human needs. It was sort of micro-cosmos that was aimed for protection against the weather disturbance, animal and criminal, and also sustaining 
family foundation, for resting and work. The house was a symbol of actualization for social economic and cultural status and other functional state. According to Silas (1983), quoted by Akil (2002), residence and residential were a process of house development which was driven by the will, the ability and the opportunities. Moreover, they were also followed by the growth of biological, social, and family economical apprehensive.

The essence of the house obtained vigorously human subsistence. However, it is constantly and potentially evolved. Greek philosopher Aristotle (Bertens, 1992, p.166), quoted by Maria (2008) said that mankind is "zoon politicon". It was interpreted as a social creature who always desired to interact and assemble with each other (living in the policy). They also desired a safe atmosphere, peaceful, comfortable and free. Thus, man could work and take a role to devote himself for others. Tradition could be a speech, beliefs, or habits through an agreement in community. According to Durkee (1987: 12-13), in Arifin (2011), said that the hurdle of tradition was related by a factor of "sustainability". Therefore, Sumalyo (2001) said that the tradition was established on intuition, instincts and habits which were passed down from generation to generation in a society from the ancestors.

With the aim of understanding the diversity of architecture at the traditional residential nearby lake Sentani, a research is needed to see the changes both in time and space dimension. The Observation objects were obtained recently and previously in a traditional house in Doyo Lama Jayapura residential in Papua. The observation elements included phase, layout, façade of the building and its architecture. The selection of the object was based on the fullness of the building which could represent the characteristics of the Sentani tribbe. This study was examined a case of a traditional residence in Traditional residential of Sentani tribe in Old Doyo village, Jayapura district in Papua.

Papua is a province located in the eastern part of Indonesia. Half of the island was Papua New Guinea which is on the eastern side. Most of the Papua's population was the Melanesian. Papua's ecology was divided into three main geographical regions or ethnic: mountain areas, coastal plains area, and the lower mainland of remote area. One of the tribes that inhabited in the coastal plains was Sentani tribe, nearby the Sentani Lake. Sentani Lake was in district of Jayapura. It is extending from east to west with a length 26,5 kilometers, and its area is approximately 9630 ha. The majority tribe in the mainland and coastal area of Sentani Lake is Sentani Tribe. The tribe has different clans in the community in every village, and they are led by a tribal chief or Ondofolo. Lake Sentani is divided into 3 major parts: East, Middle, and West Sentani. Sentani people live high building and nearby the lake. They believe that could abide them with their ancestors' spirits from generation to generation. In this study, the research location is in traditional village of West Sentani Doyo Lama, the traditional residence of Tribe Doyo Lama's chief. The purpose of this study aims to achieve the understanding of settings transformation and the meaning of traditional residence from "Sentani tribe" nearby Sentani Lake.

\section{Literature Study}

\subsection{Traditional Residence}

Rapoport (1969) state that traditional residence was a manifestation of social and cultural values of the society which were closely related to socio-cultural of the community in the process of attaining the basic norms of tradition. The tradition itself had an impact and respectful as an unwritten-law based on the community agreement. Furthermore, "traditional residence" also means a house that was built in the same way for several generations. Another term for a traditional residence was a house of tradition or house of community. Rapoport also included the house and its neighborhood as a community expression of culture, including religion, family, social structure and social relations. As an established environment, architecture can be perceived as a process and a record of the events of past which was corresponded to nowadays (Lynden Herbert, 1972).

Jon Lang (1987), states that the theory of aesthetic anatomy has adapted within the architecture study in the sense of enviromental design. Moreover. Lang acquired that the theory of aesthetics in architecture was always oriented on two main points. They are: (1). Identification / understanding about various influential factors in the existence of aesthetic experience and enjoyable in the process of observation; (2). Understanding of the human capacity for creation of or enjoyable process of creating something that is aesthetically pleasant.

Rapoport (1990) argued that the cultural and environmental built in were changed simultaneously. Every transformation was divided into three parts: (1). core element: the element that was slowly changed and it becomes the identity of the owner of the architecture; (2) peripheral element: it is a part of unimportant and easily changed or replaced; (3) .new element: it adapted by the owner of a new culture and become part of the architecture.

There are three aspects that can be used as a benchmark to notice changes in the physical environment of residential in the integrated system (Habraken, 1978). They are (1). Spatial system which is various aspects of benchmark related to space or spatial organization. It requires space system, spatial orientation and spatial relations pattern (pattern spatial space). (2). Physical system which is a benchmark of various aspects related to the construction and the use of materials that are used in creating a physical building. These systems are related to the structure, the construction of the roof, walls and floor; (3) Stylistic system that is various aspects related to the benchmark of model or embodied-form. This system includes the facade, door and window shapes, as well as other elements both inside and outside the building.

According to Rapoport (1997: 278-279), basic elements of the approach and understanding towards the use of patterns are: (1). Human activities, human activity space (home range) the general limits that consist of some settings or locations, as well as the connected network among the locations. They have certain radius home range that can be classified into the home range of daily, weekly and monthly; (2) Main area (Main Core), which is an area of human activity space. It is mostly 
used, understood and controlled directly by the population. In this context, the environment of main area is the residential neighborhoods with solid social system. They are clusters of daily activities which are arranged by group of people who is familiar with each other; (3) Territory, is an area that is closely related to private and personal space. Territoriality is also the form of ego which could not be bothered because of privacy. Territoriality itself is a pattern of behavior that related with the ownership or the rights of a person upon a place; (4) Controlled-Area (Jurisdiction). It is an area which is dominated and controlled temporarily by a group of people in the city. They also have temporary business that might control the area in different groups; and (5) Personal Distance or Personal Space. It is a distance or area with intervention of others.It is different from the previous four elements which are likely to have physical limits. Personal distance usually has no obvious physical appearance.

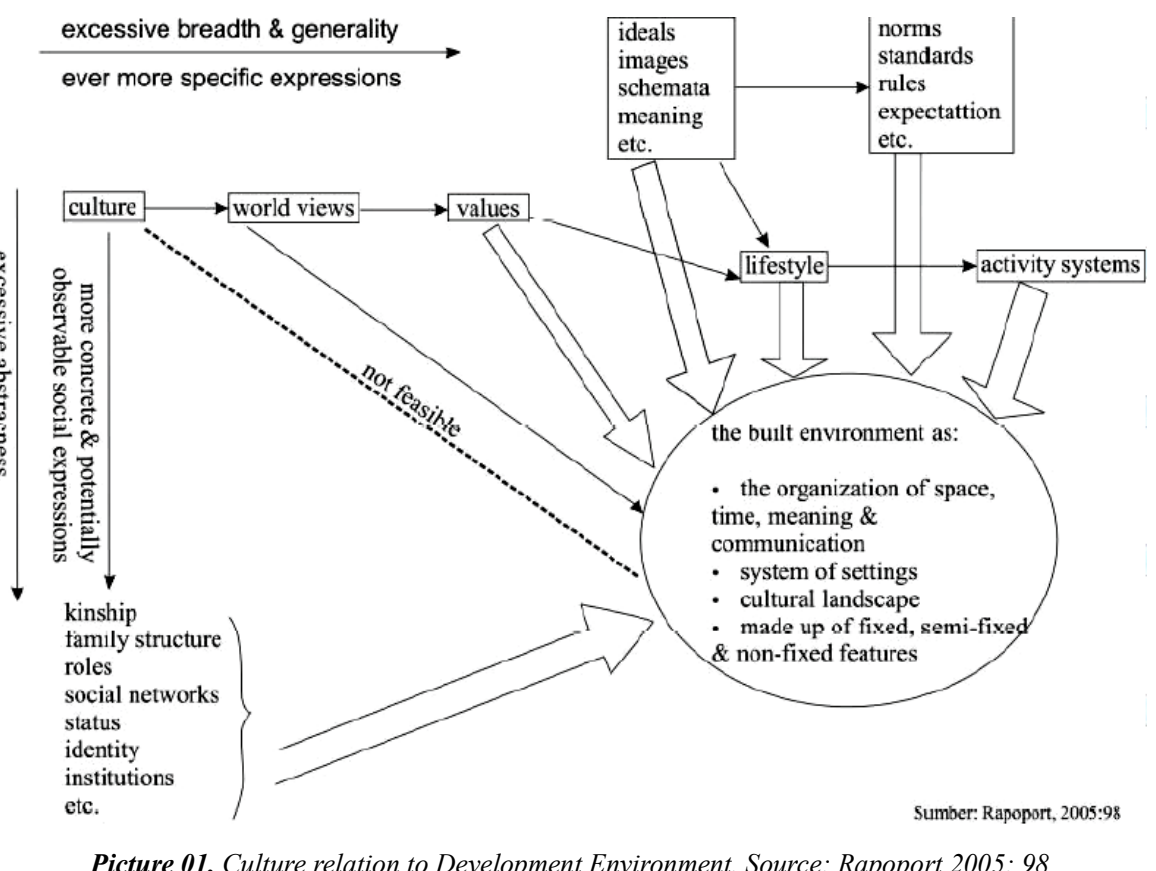

Rapoport (2005) argued that using the concept of culture is acquired in two ways. First, it is assumed that the cultural and community development environment is equivalent units, but the culture is still too abstract, so that the approach used by socio-cultural. In connection between culture and environment building, Rapoport determined the specific components of cultural expression to be more easily understood. These components include a view of the world (world view), values, norms, lifestyle and activity system (Rapoport, 2005; 94-96).

The construction of environment evolved into four components of forming. They were organization of space, system settings and made up of fixed, semi-fixed and non-fixed features. Fixed elements defined as elements that have been structured into space forming unity, such as floors, walls, and roof. This element relatively changed in the long term, in contrast to semi-fixed elements, such as furniture which has a rate of change shortly. Therefore, those elements

\subsection{Theory of Culture, Environment and Society}

Culture is the whole system of ideas, actions and man's work in the context of a society that used to belong to human beings through learning. Koentjaraningrat (1986) implies that the theoretical description is categorized in three concepts: ideas, values and norms of life from the cultural process. That was associated with the modality inside the architecture which is about form, the definition, nature and character ((Flew, 1979). The environment that is designed by a special culture is the setting for a group and special way of life. They significantly and typically distinguish from other groups. Between the way of life and being part of the symbolic system are the group's adaptive strategy in their ecological setting (Rapoport, 1980). 
relations between individuals ".

Thus, it can described that the residence and the residential transformation are influenced by the impact of social culture, including religion, kinship patterns, organizational / social groups, way of life and daily adaptation and social relations among people.

Amos Rapoport (1969: 17) said what is produced by humans is highly dependent on the social and cultural background or social condition of the man himself, so that building a house is a cultural phenomenon in which the shape and organization is strongly influenced by the culture in which it is located. From Amos Rapoport's opinion, it can be concluded that house feature is not only influenced by physical forms alone or be influenced by factors that stand alone, but also a result of the overall socio-cultural factors that can be seen in the patterns broadly. The formed environment would reflect the impact of socio-cultural, including trust, kinship, social organization, ways of life, and social relations between individuals.

\section{Research Method}

The research method, in the scope of Architecture, is aimed to prove, test or develop a concept or theory. The research method obtained the process of validating which is maintained by logical considerations based on the measurable analysis.

Therefore qualitative research is used as research methods. Bogdon and Taylor (Moleong, 1997), said that "qualitative methodology" was defined as a research procedure that produces descriptive data in the form of written or spoken language from people and objects that were observed. Qualitative research is dealing with the interpretation and understanding of the current situation or ongoing. It emphasizes on the role of the researcher as the important part. The researcher is the "objective observer" of the research tools. Data would be obtained from observation, a list of open-ended questions, and interviews on the real background (natural setting), which were focused on the respondent's ways of thinking.

According to Groat and Wang (2002), a case study has 5 characteristics. One of them which were used in this study was the characteristics on single case center. This method implied more on studying the phenomenon that has happened within dynamic situation.

The field research of social culture was using qualitative methods with a single case study at home chieftain in the village "Doyo New" in the traditional settlement rate Sentani. Furthermore, this methods were used to find the meaning and search for the room, ornaments, and the structure of the house in a traditional home Sentani tribe in Papua province, Indonesian

\section{Results and Discussion}

\subsection{House of "IMAEKHOLU": The Existing of Sentani's Traditional Residence}

The research location was in traditional residence on
Sentani tribe in Jayapura, Papua. This case study focused on traditional residences which still remain their authenticity of Sentani traditional residence, especially the house of Doyo Lama's chief.

Doyo Lama Village is located on the seashore of Sentani Lake, Jayapura district, about $50 \mathrm{~km}$ from the city of Jayapura. Traditional village Doyo Lama has a unique life, community people mingle with the traditional society of different clans, Christian, but still powerful maintain ancestral customs, such as the various ceremonies, ceremony of the great days of Christianity, the form of the house. The numbers of residential house are approximately 85 buildings, in addition to the church, traditional house and meeting place residents.

Residential environment is a group of various artifacts that occur due to the merger between the site, events and sign. Roads, open space, building type, and other physical elements of the whole site are the sign of a certain event. It proved an eternity (permanence) which was so complex characterizes of residential environment (Rossi, 1984).

A residential building could be the evidence of people's activities. Just by looking at the front and the shape of houses, one could conclude building what he saw. The special feature of this residence or identity of people would be recognized as the building with other functions. Charles Correa (1983: 10), as quoted by Arifin (2010), said that the appreciation of the identity or identities would increase sensitivity not only to the environment but also on society. The concept of form in the context of traditional culture is heavily influenced by the meaning of the symbol of the micro-macro cosmos, the natural elements around as well as the relationship with the social status.

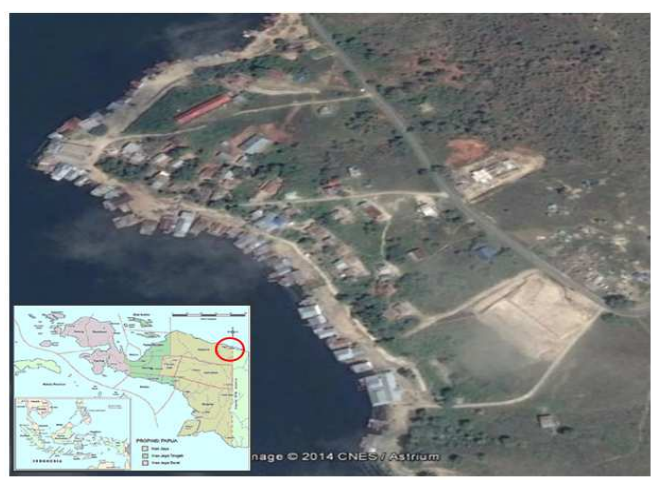

Picture 02. Map of Location in Lake Sentani and Doyo Lama village in Foto. Source: Google Earth 6 November 2014

Rapoport (1969) described the basic physical elements of neighborhoods, such as, climatic conditions, construction methods, available materials, socio-cultural and technological factors affecting the change in shape of the house. The discussion about the chief's house (Naphtali Nukuboy) was obtained based on the analysis of the house feature, the relationship of system activity and setting, and the lifestyle changes.

\subsubsection{The House Feature of "IMAEKHOLU"}

The house of "Imaekholu" that was observed from the 
beginning was about to change in blue print and it affected the circulation system in the room. The arrangement of setting was still the same with the original form which gave the tradition meaning. The study of theory Rapoport (1982) divided the elements of space based on three parts: (a) fixed feature element. It is the element that has the properties of static or fixed and cannot be eliminated, most of the standard architectural elements such as walls, and ceiling. (b) Semi-fixed feature element. It is the element that has the free nature, the space as a result of changes in home furnishings, curtains and other supplies. (c) Non-fixed feature element. It is the element that has the free nature is the result of changes in space. It is very tied to the human residents of a place, its spatial displacement relationship (proxemics), the position and posture (kinesics).

Fixed feature elements were found: (1). Wall House still using "gaba-gaba" as the partition and their boundaries were clearly distinguished the rooms of men and women; (2). Floor boards and home use coconut shell; (3). The walls that restrict women and men are still clearly visible on the home / sketch above, still the same meaning in the division of the room setting; (4). Dividing wall workspace women, cooking, boat landing and food as well as women are still placed on the back of the house, give a sense of protection towards women.
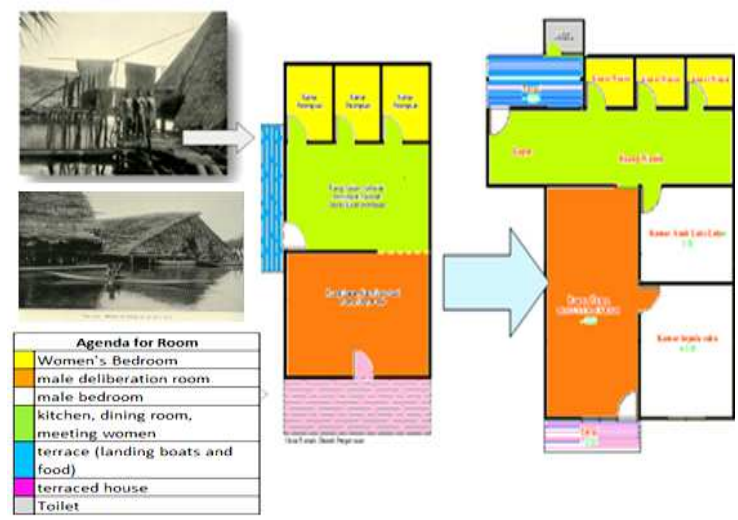

Picture 03. Plan "Imaekholu" Early and Existing. Source: Nova Guinea Vol. III, (1907), and Survey 2014.

The Blue Print of Imaekholu House based on traditional residence from the beginning until now:

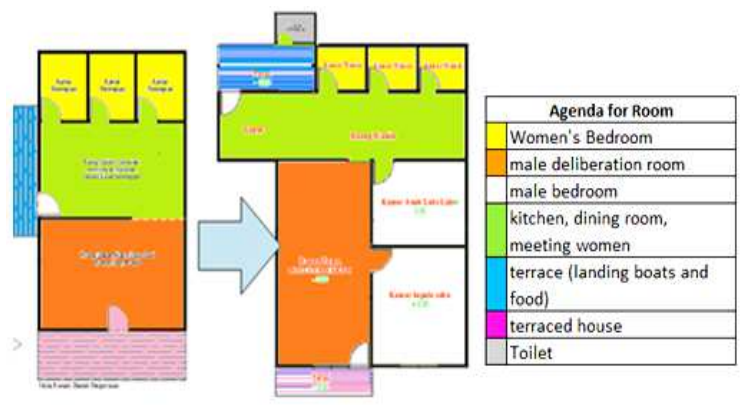

Picture 04. Traditional house "Imaekholu" Then past and current Existing Home Chieftains Nukuboy Naphtali Doyo Lama village. Lake Sentani. Source. Survey 2014
According to Rapoport (1977), the environment was able to reflect the pursued-values, the desires and habits of the people. Thus, if the value, the desires and habits changed, there would be transformation in the spatial context. The purpose of the room that is still maintained and changed is shown by the table 01 .

Table 01. Meanings room of the dwellings. Source: Analysis of the author

\begin{tabular}{|c|c|}
\hline \multirow[t]{7}{*}{ Colour } & Information \\
\hline & $\begin{array}{l}\text { The Pink color, on the front of the house (terrace) is still in the } \\
\text { same position, serves as the entry into the dwelling house }\end{array}$ \\
\hline & $\begin{array}{l}\text { The Orange color as the deliberation room, conference and } \\
\text { meetings, located at the same position and setting the open } \\
\text { expanse of the board model "open setting" that is not filled by } \\
\text { elements of the interior. }\end{array}$ \\
\hline & $\begin{array}{l}\text { The Green color, as a space where cooking, eating. The dining } \\
\text { room is called the space of the woman lying on the back with a } \\
\text { large open space and have access to a boat landing / food }\end{array}$ \\
\hline & $\begin{array}{l}\text { The Yellow color, as a sign of women bed room, located at the } \\
\text { position behind home interpret as a place that is protected and } \\
\text { maintained. }\end{array}$ \\
\hline & $\begin{array}{l}\text { The blue color, as a sign of the boat landing area and a decrease } \\
\text { in food ingredients, which is located at a position above the } \\
\text { water and behind the house with access to the kitchen area }\end{array}$ \\
\hline & $\begin{array}{l}\text { The White color, marking the addition of room for men. The } \\
\text { space shows the differences in the form of the house with the } \\
\text { initial condition. the interview said } 2 \text { (two) bedroom is a } \\
\text { room-headed households and men who are not married. Setting } \\
\text { the access room and the door to the dining room and the women } \\
\text { showed a change in position between men and women, the } \\
\text { increase in women's gender status changes Sentani tribe and } \\
\text { lives as a family (husband and wife). }\end{array}$ \\
\hline
\end{tabular}

The transformation of the setting was happened in the community meeting room. At the beginning, the community meeting room was used for conference room and the meeting room for male community and, at night, also functioned as a resting place. The main function community meeting room was for the security in the neighborhood. The meeting room was transformed with the addition of special bedrooms for men who are not married yet, and the existence of the access door to the room the women gave the meaning of acceptance of women's gender status in Sentani Tribe. It is seen from the location of the access door to the room and the dining room area women. The first bedroom on the front is intended for the chief of the tribe and his wife, while the second room is for the boys who have not married yet.

From the analysis above showeds a pattern similar spatial arrangement between the two, both in terms of the hierarchy of space and function space in it. Principles contained in the hierarchy of spatial pattern characterized by levels or differences in the value of each space is divided into successive gradations ranging from the front or the general public towards the rear to the special or private and sacred, as one manifestation of the concept of the macrocosm and microcosm, and has a logical consequence of the activities carried out at home stay the chief of the tribe inside. It was explained by Hidayatun (1999: 38).

It can simply be described as interconnected residence. Therefore, the individual units are separated along both walls, 
floor, or ceiling. Even more importantly, the individual units are separated the use of open spaces and existing facilities. Historically, configuration and scale group experienced only because of the limitations of material resources and intelligence communities who built it. Traditionally, the scale and the organization from the residential groups have described not only the physical setting but also social settings, as it was said by Untermann (1983: 1). He argued that the residential neighborhood was the most fundamental form of human residential. Symbols at home structure containing the following meanings:

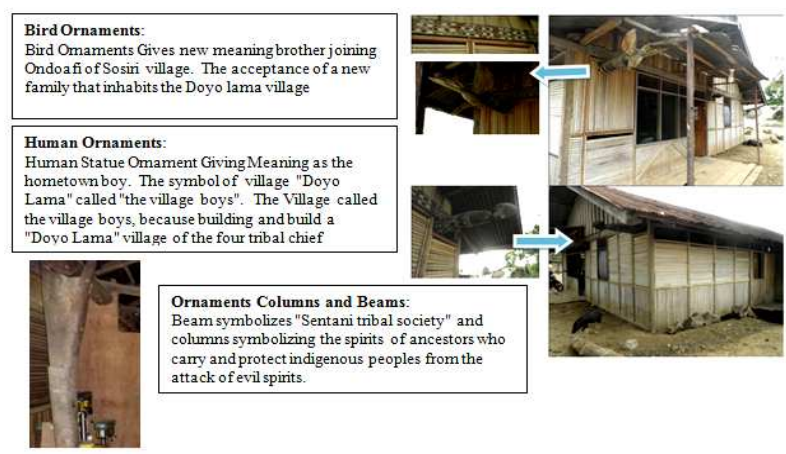

Picture 05. Traditional house "Imaekholu" Meaning of Symbols / Ornaments in dwelings. Source: Survey 2014

The sign in fixed element is something that can represent or express something else which will stimulate a response from the mark reader. Significantly, every sign that was created is to convey the message, or a sense. The symbol is the kind of sign which means not all types of sign is a symbol, according to Pierce and Charles, 1970, as quoted by Marcus (2007).

Thus, the symbols are used in "Imaekholu" residence is a sign that manifested a visual form of communicative characteristic of Sentani society. The symbol in traditional Sentani society tribe cannot be separated from general normative of social unity. It can be understood by supporting community members based on the values prevailing in the social system of traditional Sentani community. The symbol means for a sign to tell something to someone. Symbols are the media representation of the values of trust in physical feature, especially architecture as explained by Pierce and Charles, (1970) whom were quoted by Marcus (2007).

Fixed feature element in the residential element of "Imaekholu" still has a static or permanent nature which cannot be removed from the symbol of culture and still remained until now, including: (1). The house walls are still using "gaba-gaba" and their partitions are firmly separated between men and women, and setting of space function still remains. (2). Beams of the House are made of Human and bird-shaped ornaments (Nature); (3). Column and beam system is still using the original model. It is "hukulu Kai" which is beams above the column; (4). The floor is using boards and boards from the skin of coconut tree.

The use of symbols and signs in Sentani residence progressively decreased. Nico Tanto (the Employee of Museum of Anthropology Cendana University) said that seventy years more people in the villages did not carve. Previously, missionaries and the Dutch government did not allow people to carve, then it continued until 1992. Finally, they carved again. However, when the gospel came to the area of Lake Sentani, in early 1900s, they reflected their beliefs to the carving object which had magical powers of the spirit. Then, they burned and sunk it into the bottom of the lake. Once more, the community forbade all kinds of sculptures. "At that time, the Dutch government and Protestant Christian missionary were quite hard to prohibit all sculptures. Even the Dutch government policy burned all the houses of men, education center for young people is quite instrumental in the destruction of culture carving around Sentani Lake, "said Nico. In the Dutch period, anyone who carved sculptures would be fined or imprisoned by the Dutch police. Visible columns with carved symbols of human nature and heritage were still planted in front of the residence of the tribe's chief.

\subsubsection{The Structure of Traditional Building}

Firstly, the transformation of the main pillar in the house of Sentani tribe communities was called the "hukulu". It is inverted swan tree roots and was carved as a custom symbol. Secondly, the transformation in the shape of "hukulu" to replace it with a form of "hukulu kai" which is an inverted tree trunk swan-shaped "Y". It is as the base of the house roof beam. Thirdly, the round tree trunk was cracked to place the beam, as shown in Figure 07. The building structure of traditional residence and residential communities in Sentani Lake Sentani consists of: Foundation that consists of poles planted in the bottom of the lake also serves as a buffer beam and floor. They are united / amplified using ropes of rattan or skin of wood.; Part of the Building Body, that consists of walls and floors, the materials which are used of the sago palm wood. They are supported with logs or beams among the main poles.

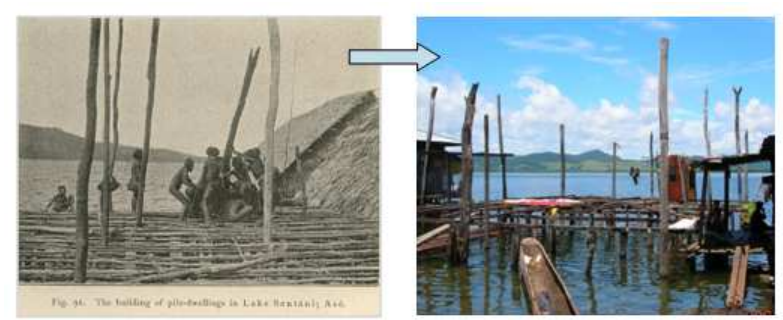

Picture 06. Structure from "Imaekholu" House Early and Existing. Source: Nova Guinea Vol. III, (1907).

Changes in house construction is shown in a fixed feature element on the system structure of "Imaekholu" house which still is remained as the traditional value. It still used of Wood Column of "hukulu Kai." It is also used at "Imaekholu" house of the chief tribe. The use of wood materials from wood or iron wood black Swan is still used; building remained above the water surface with a model house on stilts. Semi-fixed feature element which is an element of free properties on the material is shown. The wall is changed from sago leaf material to sago tree trunk (gaba-gaba); then, the use of wood materials change from swan wood to iron wood. Changes in this system is affected by changes in lifestyle is getting more 
modern and availability of wood material from trees "Soang" increasingly limited.

\subsubsection{The Roof Section}

The roof consists of "kuda-kuda", "gording", rafters and roof coverings. The materials for roofing used sago leaves knitted / assembled into a single unit, all put together with rattan ropes and wood skin.
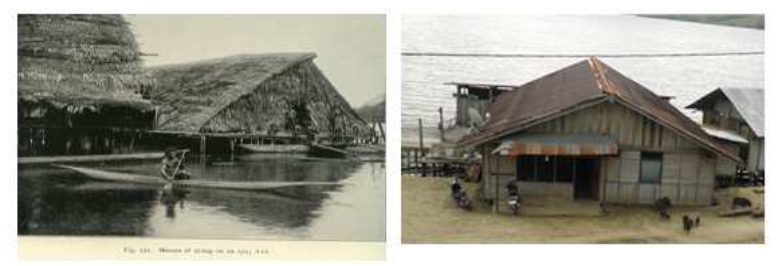

Picture 07. Shape Home "Imaekholu" Early and Existing Source: Nova Guinea Vol. III, (1907).

Fixed feature element in the form of dwelling "Imaekholu" fixed saddle-shaped. Semi-fixed feature element is the free elements, the result of transformation in space as shown in the use of wall material from sago leaf material to sago tree trunk (gaba-gaba); the use of the roof covering material using from sago palm leaves to tin roof .; the use of jalousie windows, and the shape of the house.

Traditional house of Sentani tribe still has a reflection of the cosmological phase that occurs in particular on (i) attached to the system relatives and social orientation, (ii) Adapted from the natural conditions challenges; (iii). Technology use of wood is still very dominant / stand; (iv). Traditional orientation of the house in particular is still a very important orientation in traditional residence. Mintarja (1991) expressed the results which were the traditional Indonesian architecture reflected the cosmological phase.

\subsection{Relationship between Activity Systems and System Settings in "Imaekholu" Housing}

The way of life of Sentani people, their beliefs, values and the beliefs in ancestors held norms will determine the behavior of peoples or individual who reflected the way of life and his chosen role in the community, both community tradition and traditional leaders. The system of human activity will be determined by the cultural and social context as it is said by Rapoport, (1977). Way of life and system activities will determine the manner and place for such activities. The spaces are interconnected a spatial system and the function of place for the event. Neighborhoods as part of the work of architecture that evolved the tradition of local community are a direct picture of the cultural community.

The activity room in the residential setting is space setting formed from the diversity of user activity in response to the environment and the overlap among the formed-activities. The space that is formed by the activity of the society is the social space. Its utilization is not personal, but it is obtained by a few people and society. Thus, it can be concluded that the social space is a space that can be limited by one or all three elements forming space, namely the element fixed, semi-fixed and fixed. As it is stated by Rapoort (2005), social space was also influenced by social aspects in the residence, values, Life style and norms affected activity and setting system.

Changes in people's lifestyles Sentani tribal influenced by lifestyle factors such as age, occupation, marital status, education, and income, affect the social life of the community, it appears can be seen in the cultural and social changes of indigenous peoples, and the style of residential architecture shows socioeconomic status and personality of the society, and often the public to raise the image of him, it is implied by Cherulnik \& Wilderman, (1986); Cooper, (1976); Nasar, 1989.

It can be concluded that the relationship between culture, behavior, system activity and system settings, influenced of human cultural backgrounds such as live view, espoused beliefs, values and norms are held will determine the person's behavior is reflected in the way of life and the role that chosen in the community. Cultural and social context will determine system activity or human activity. Way of life and the system will determine the kinds of activities and a forum for such activities. The containers are spaces that are interconnected in a spatial system and functions as a venue for the last activity. This is a system of spatial settlement patterns and structures as said by Saso (2002).

Lifestyle that changes Sentani tribe communities has an impact on the activity of the system changes in traditional residential homes. It is as it says Rapoport (2005), that the system activity is influenced by the lifestyle.

Activity and Setting System in "IMAEKHOLU" House.

Basic activities of public interest Sentani influenced by several aspects such as Indigenous aspects, social and religious. The basic activity can form a repetitive activity, resulting in social spaces. The symbolic aspects of the house are respect of the cosmological orientation. Community activities in general can be divided into two groups of activities: activities that are sacred (relating to religion activities), and activities that are profane (related to social activities). The placement of these activities is distinguished based on the orientation of sacredness.

\subsubsection{Activities Gathering and the Meeting}

The gathering in the chief's house is the activity which can strengthen family relationships, neighbors and unity of the clan. Gathering activities and the meetings made at the time there are things that need to be discussed in "koselo-koselo" (house) tradition in decision making. Gathering activities are also carried out among family do after eating or when there is spare time, usually greetings and telling daily activities. Thus, it is put in front of the house which is without chairs and sitting on the floor.

This activity is influenced by time, and can affect the spaces used. Social space in the variable of the basic needs is influenced by the nature of the activities that have gathered together a family or clan from the neighborhood, so the space is used instead of the private space. Fix element that is still remained among others: 1 . The wall is made of gaba-gaba and boundaries clearly defined spaces; 2 . Columns and beams, still 
using the original model that is "hukulu Kai"; 3. The floor residential use and functioned as a board the meetings.

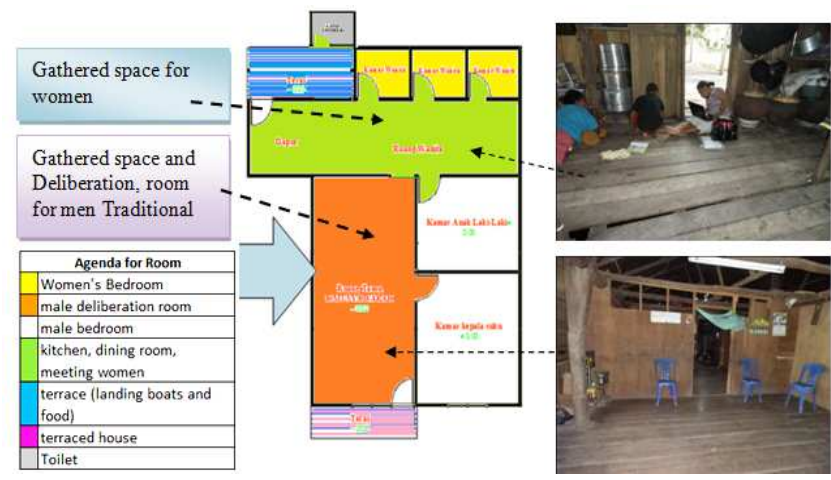

Picture 08. Activities Gathering And The meeting

\subsubsection{Eating Activity}

The layout of the dining room in the house is at the back of the head of the tribe. It is nearby the kitchen which related to the access of quayside and food. Eating activity is closed to the activity of cooking (kitchen). It is used by the mother to cook and serve food to eat with the family that made mothers areas. It is also influenced by the layout of the dining table in the kitchen to put utensils for food and drinks. If there is a large family who came, they will use women's room to eat together by sitting on the floor with men as a whole family.

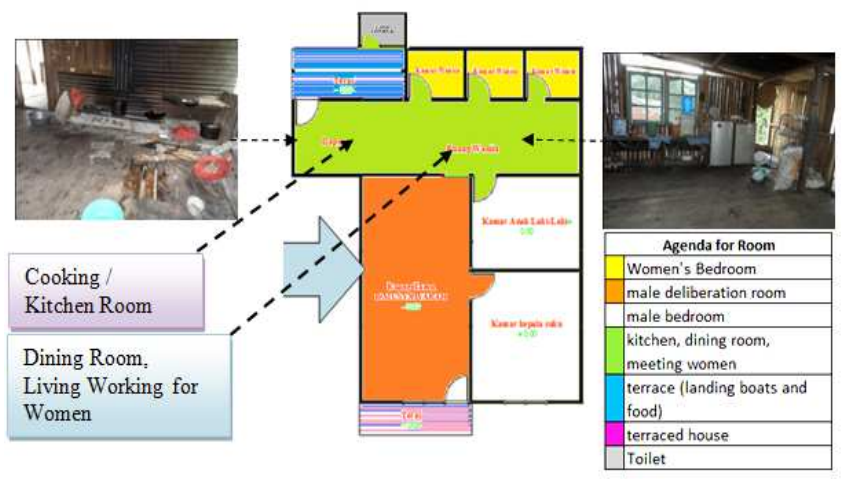

Picture 09. Eating Activity in "Imaekholu” House

Social room for eating activity is strongly influenced by the activities of the occupants. Sitting on the floor and eating activity carried on wooden floor. This activity happened nearby the kitchen and was in the area of women, to facilitate the activity. Fix element that is still remained among others: 1. The house walls are made of gaba-gaba and boundaries clearly defined spaces; 2 . The floor board using, as a place to eat.

Semi-fixed elements can be characterized by the presence of a refrigerator, a table laid utensils for eating, drinking places. Dining room, kitchen, and a quayside and the food is well-cared for, this is supported by the opinion of the Altman. He convinced that usually the back of the house is not well-cared, because the back of the house is rarely accessed by others (Altman \& Gauvain, 1981).

\subsubsection{Guests-Received Activity}

The layout of the room to receive guests is distinguished between men and women. Men usually speak in the front space of the house, where an important thing to be asked to enter the living room. It is different if the guest is a woman who may be seated mother's room. Guests who are relatives usually directly are accepted in the living room. Social space on the basis of the activity variable-vacancy is greatly influenced the nature of the activity itself. Received and invited guests mean other people who are not residents of the house to enter the house. Therefore, there is a limitation of space for receiving guests, it is concerned if the owner is the chief of the tribe.

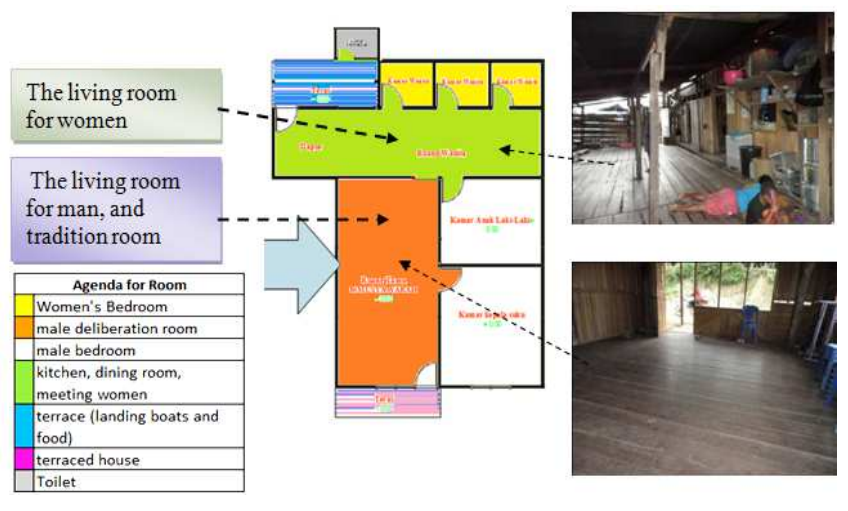

Picture 10. Guests-Received Activity

Social space for receiving guests is strongly influenced by the activities of the occupants. This activity has a tendency to be on the front of the house for the male respondents. Semi-fixed elements characterized by the available table and guest's chairs in the living room. Fixed elements were seen clearly that each room is limited by a wooden wall; especially there is a door to get to the room. It is the evidence of boundaries between residents and guests. It can be concluded space is a semi-public space. Most of the front of a house is a place of each person to express themselves and also places for adapting to the standards and social skills of neighborhood (Altman \& Gauvain, 1981; Gauvian, Altman, \& Fahim, 1983).

\subsubsection{Resting Activity}

The layout of the rest room in general was in the middle of the house for men and the back of the house is for women. The layout or setting is because the middle and front of a special house for men is a space that serves to maintain the security for women. Resting room for women is on the backward because it is the most conducive place for resting, and aims to protect. Then, the changes occur in the system settings bedroom for men. A special room is reserved the chief of the tribe at the front and the second bedroom is used for men who are not married. When there is a party and they invited a large family, the meeting room will be used as a sleeping / resting together. 


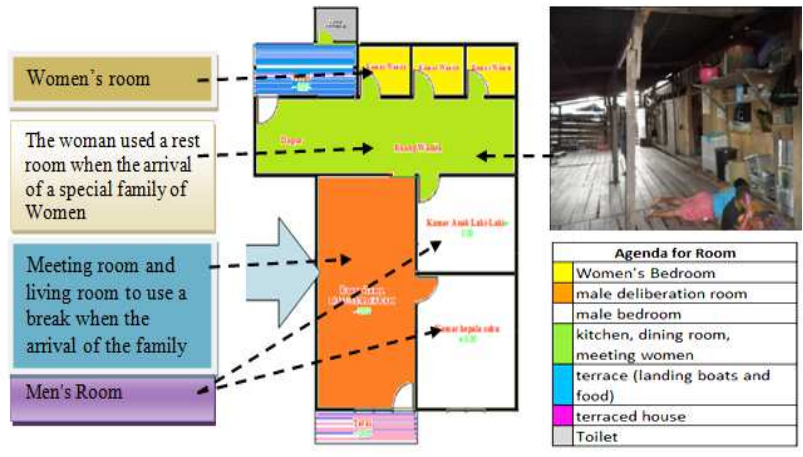

Picture 11. Resting activity

Resting activities is very private activity which depends on the occupants of this activity. Thus, this activity is also limited by the fixed elements such as wooden walls. There are activities that are not allowed which are located in the signed-space by semi-fixed elements. There are the mattress where the occupants are doing this activity are women or some family members. The fixed element is seen in resting activity. There are walls that limit the rest with the other space. In this space there is also a door that suggests that there should be a license if you want to enter this room, even for the residents.

\subsubsection{Bathroom Activity}

The layout of the bathroom (MCK) is generally located at the rear of the house. Its layout is as "cubluk" toilet. However, for bathing and washing, they are done in the lake directly. The changes occur in the system settings that at the beginning were open bathroom became the bathroom with the sanitation system in the model of "cubluk" closed-toilet. However, for bathing and washing remain the same in the lake.

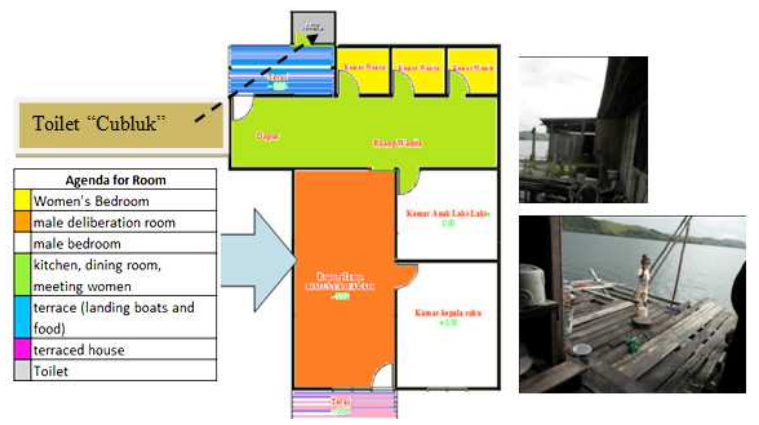

Picture 12. Bathroom Activity

\section{Conclusion}

The transformation of the residence of Sentani tribe is affected by changes in lifestyle / life style that affect system activity in space. Transformation in people's lifestyles becomes a modern society which brings about changes in system activity and system settings in the traditional residence of Sentani tribe society. Traditional house in Lake Sentani Sentani tribe generally remains the identity although some elements tend to remain but in visual shape.

System activities that occur inside the home are the influence on social life as Sentani tribe's basic needs. The changes in settings and meanings of residence were formed due to the activity of people tradition. They occur in social spaces of the residence. The utilization of those spaces was not only personal, but also openly public as traditional area. Therefore, the distribution of the "territory" of men and women are likely to change.

The transformation in the social culture Sentani tribe of the village of "Doyo Lama" affect: (1). Changes in shape of the house "IMAEKHOLU" which its meaning of closed to open more modern; (2). Changes in the spatial arrangement bed male and female, which have access to the dining room and living room shared between men and women. Thus, it means that there was no gender difference. (3). Change is not entirely the case, there still exists a fixed element in the structure of the building provides a symbol of culture / customs, building materials and elements. They remain in the traditional meeting room that is specifically used by men in discussing indigenous issues. The Traditional settlements in Sentani tribal is an asset that must be maintained as Indonesian cultural wealth of the nation Therefore, it can be used as a traditional residential tourism areas.

\section{References}

[1] Altman, I and Chemers, M (1980) Culture and Environment, Monterey, California Brooks Cole.

[2] Hadi, Sutrisno. (2000). Metodologi Research. Yogyakarta: Andi Yogyakarta.

[3] Habraken, N.J., 1982, Tranformation of the Site, Combridge,Massachusetts Summer.

[4] Haryadi dan B. Setiawan, 1995, Arsitektur Lingkungan dan Perilaku; Suatu Pengantar ke Teori, Metodologi dan Aplikasi. Proyek Pengembangan Pusat Studi Lingkungan Direktorat Jenderal Pendidikan Tinggi Departemen Pendidikan dan Kebudayaan Republik Indonesia.

[5] Hidayatun, Maria I. 1999. Pendopo dalam Era Modernisasi: Bentuk, Fungsi, dan Makna Pendopo pada Arsitektur Jawa dalam Perubahan Kebudayaan. Dimensi Teknik Arsitektru, 27, hal. 37-46.

[6] Koentjaraningrat, 1990, Pengantar Ilmu Antropologi, Rineka Cipta, Jakarta.

[7] Koentjaraningrat. (1982). Sejarah Teori Antropologi I. Jakarta: UI Press

[8] Moleong, Lexy, J. (2001). Metode Penelitian Kualitatif. Bandung: Remaja Rosdakarya.

[9] Pratiwi, W. (2009). Tourism in Traditional Bali Settlement: Institutional Analysis of Built Environment Planning. Verlag Dr Muller.

[10] Marcus Gartiwa \& Sri Sularti (2007) Pengaruh nilai-nilai kepercayaan Masyarakat kampung naga terhadap Arsitektur tradisional sunda, Sosiohumanitas, IX (2), 15 Agustus 2007.

[11] Mintardja, J., (1991). Kompendium Sejarah Arsitektur Indonesia, Mulia, Jonas, 1998/1989, Pengaruh Elemen Bentuk Terhadap Karakter Rumah Tradisional Sunda, Fakultas Teknik Jurusan Arsitketur Universitas Katolik Parahyangan, Bandung 
[12] Rapoport, Amos (1969), House Form and Culture, Prentintice Hall,Inc, Englewood Cliffs, New York.

[13] Rapoport, Amos (1977), Human Aspects of Urban Form, Towards a Ma-Environment Approach to Urban Form and Design, Pergamon Press, Oxford. New York.

[14] Rapoport, Amos (2005), Culture, Architecture and Design, Locke Science Publishing Company, Inc, Chicago.

[15] Rosmiaty Arifin (2010) , Perubahan Identitas Rumah Tradisional Kaili Di Kota Palu Jurnal " ruang " Volume 2 Nomor 1 Maret 2010 Jurusan Arsitektur Fakultas Teknik Universitas Tadulako
[16] Sasongko, I. (2002). Transformasi Struktur Ruang pada Permukiman Sasak, Kasus: Permukiman Desa Puyung. Jurnal ASPI.2 (1):117-125.

[17] Untermann, R.K., and R. Small (1983). Site Planning for Cluster Housing (Perencanaan Tapak untuk Perumahan). Penerjemah: Vincent M. Intermedia. Jakarta.

[18] http://www.mongabay.co.id/2013/07/04/nasib-miris-seni-patu ng-dari-sentani/ download tanggal 31 November 2014 